\title{
POLYMORPHISM OF ANGIOTENSIN-CONVERTING ENZYME (rs4340) AND DIABETIC NEPHROPATHY IN CAUCASIANS WITH TYPE 2 DIABETES MELLITUS
}

\author{
Šeruga $\mathrm{M}^{1, *}$, Makuc $\mathrm{J}^{2, *}$, Završnik $\mathrm{M}^{3}$, Cilenšek I ${ }^{4}$, Ekart $\mathrm{R}^{5}$, Petrovič $\mathrm{D}^{4}$ \\ ${ }^{*} \mathrm{M}$. Šeruga and J. Makuc contributed equally to this study.
}

\begin{abstract}
*Corresponding Author: Professor Dr. Daniel Petrovič, M.D., Ph.D., Institute of Histology and Embryology, Faculty of Medicine, University of Ljubljana, Korytkova 2, 1000 Ljubljana, Slovenia. Tel: +386-1-543-7360. Fax: +386-1-543-7361. E-mail: daniel.petrovic@mf.uni-lj.si
\end{abstract}

\begin{abstract}
Diabetic nephropathy (DN) is the leading cause of endstage renal disease (ESRD) in developed countries. Several environmental and genetic factors predict the development and progression of $\mathrm{DN}$. The renin-angiotensin system was demonstrated to be involved in the development of DN. We evaluated the association between rs 4340 of the angiotensinconverting enzyme $(A C E)$ gene and DN in Caucasians with type 2 diabetes mellitus (T2DM) in 276 Slovenian patients with T2DM who had DN, and 375 patients without clinical signs of DN. Genetic analysis was performed with either standard polymerase chain reaction (PCR) (for rs4340). Results were analyzed using the $\chi^{2}$ test and multivariate logistic regression analyses. We found no association between rs4340 and DN. Cystatin C was significantly higher in the $\mathrm{DN}+$ group $(p<0.001)$ than in the DN group. Cystatin C was a better marker for the estimation of renal function than estimated glomerular filtration rate (eGFR) according to the modification diet in renal disease (MDRD) equation $\mathrm{mL} /$ min. We concluded that there was no association between the rs 4340 of the $A C E$ gene and DN in Caucasian patients who have T2DM.
\end{abstract}

\footnotetext{
${ }^{1}$ Department of Internal Medicine, General Hospital Murska Sobota, Murska Sobota, Slovenia

${ }^{2}$ Department of Internal Medicine, General Hospital Slovenj Gradec, Slovenj Gradec, Slovenia

${ }^{3}$ Department of Endocrinology and Diabetology, University Medical Centre Maribor, Division of Internal Medicine, Maribor, Slovenia

${ }^{4}$ Institute of Histology and Embryology, Faculty of Medicine, University of Ljubljana, Ljubljana, Slovenia

${ }^{5}$ Department of Haemodialysis, University Medical Centre Maribor, Division of Internal Medicine, Maribor, Slovenia
}

Keywords: Angiotensin-converting enzyme (ACE); Diabetic nephropathy; Insertion/deletion (I/D) gene polymorphism; Type 2 diabetes mellitus (T2DM).

\section{INTRODUCTION}

Type 2 diabetes mellitus (T2DM) is a multifactorial chronic metabolic disease characterized by post-prandial hyperglycemia that causes long-term macrovascular or microvascular complications. Microvascular complications are diabetic nephropathy (DN), neuropathy and diabetic retinopathy (DR) [1,2]. Diabetes mellitus (DM) is the most common cause of chronic kidney disease and end-stage renal disease [1,2]. In the pathogenesis of $\mathrm{DN}$ several environmental, genetic, and epigenetic factors are involved in complex interactions [3-5].

In $\mathrm{DN}$, there is a major decrease in glomerular filtration rate (GFR) together with a rise in the excretion of proteins in urine [6]. The pathogenesis of $\mathrm{DN}$ is related to uncontrolled or chronic hyperglycemia and is characterized by hypertrophy of glomeruli, hyperperfusion, thickening of basement membranes and glomerular hyperfiltration. There is microalbuminuria and subsequently, progressive glomerulosclerosis, but tubulointerstitial fibrosis may occur, eventually leading to reduction in GFR [1,2].

In progression of DM and its complications, many risk factors are involved, e.g., hypertension, dyslipidemia, smoking, obesity, aging and insulin resistance $[7,8]$. Clinically, non pharmacological interventions such as strict glycemic and blood pressure control, decrease in smoking and in dietary protein intake, have been shown to slow the progression of $\mathrm{DN}$. The most validated clinical strategy 
for slowing disease progression is therapeutic targeting of the renin-angiotensin aldesterone system (RAAS) $[9,10]$.

Genetic polymorphisms of the RAAS system may affect the progression of DM and its complications, whereby angiotensinogen, angiotensin receptor and angiotensinconverting enzyme $(A C E)$ gene polymorphisms have been implicated in the pathophysiology of DN [11]. Angiotensin-converting enzyme converts angiotensin I into active octapeptide angiotensin II, and inactivates bradykinin via the kalikrein-kininogen system [12].

The ACE insertion/deletion (I/D) gene polymorphism (rs4340) is a $287 \mathrm{bp}$ sequence of DNA in intron 16 of the $A C E$ gene on chromosome $17 \mathrm{q} 23$, whereas there are a few polymorphisms that are in a linkage disequilibrium (rs 4341, rs4646994) in some populations [13]. In adults, plasma ACE does not change with age and it is only influenced by environmental or lifestyle factors to a minor extent [15-17]. Compared with rs4340 insertion/insertion (I/I) homozygotes, circulating ACE levels in plasma were found to be nearly 30.0 and $60.0 \%$ higher in $\mathrm{I} / \mathrm{D}$ heterozygotes and deletion/deletion (D/D), homozygotes, respectively [14]. A meta-analysis of studies on glomerulosclerosis reported that the overall frequency of the $\mathrm{D}$ allele was $54.0 \%$ [13]. Overall frequency of the D allele was unrelated to gender but there were ethnic differences [13].

The $A C E \mathrm{I} / \mathrm{D}$ gene polymorphism, which correlates with circulating ACE concentration, may be implicated in the etiology of $\mathrm{DN}$, but it has been poorly investigated while giving inconsistent results [18-20]. The present study was undertaken to evaluate the association between rs4340 of the $A C E$ gene and DN in Caucasian patients with T2DM.

\section{MATERIALS AND METHODS}

We enrolled 651 unrelated Caucasians with T2DM from outpatient clinics of the University Medical Centre Maribor and the General Hospitals in Murska Sobota and Slovenj Gradec, Slovenia. Two hundred and seventy-six patients also had DN (cases) and 375 subjects with T2DM of more than 10 years duration but no clinical signs of DN (controls) were enrolled in the study. Diagnosis of DN was made according to the World Health Organization 1999 diagnostic criteria [16].

We excluded patients with overt nephropathy, poor glycemic control, significant heart failure New York Heart Association classification II-IV (NYHA II-IV), alcoholism, infection and other causes of renal disease. The study was approved by the National Medical Ethics Committee and was performed in compliance with the Helsinki declaration.
After informed consent for participation in the study was obtained from all patients, a detailed interview was made.

Biochemical Analyses. Total serum cholesterol, low-density lipoproteins (LDL), high-density lipoproteins (HDL), triglycerides (TGs), serum cystatin C, fastingserum glucose, serum glycemic $\mathrm{Hb}\left(\mathrm{Hb} \mathrm{A}_{\mathrm{lc}}\right)$, serum urea, serum creatinine were determined by standard biochemical methods. Albumin-to-creatinine ratio was also determined for each patient in three urine samples, according to the diagnostic criteria. To assess the kidney function, we used the modification diet in renal disease (MDRD) equation and serum-cystatin C $[21,22]$.

Genotyping. Genomic DNA was extracted from 100 $\mu \mathrm{L}$ of whole blood using a Qiagen isolation kit (Qiagen $\mathrm{GmbH}$, Hilden, Germany) following the blood and body fluid spin »V3« protocol. The protocol was supported by five different reagents (QIAgene DNA Blood Mini Kit; Qiagen $\mathrm{GmbH}$ ): buffer AL, 96.0\% ethanol, buffer AW1, buffer AW2, buffer AE and appropriate amount of proteases $(285 \mu \mathrm{L}$ of proteases $/ 200 \mu \mathrm{L}$ of blood). From 200 $\mu \mathrm{L}$ of blood, 3-12 mg of genomic DNA, i.e., 30-40 ng/ $\mathrm{mL}$ were extracted according to the instructions of the manufacturer.

The protocol for rs 4340 polymorphism of the $A C E$ gene was as follows: one cycle at $94{ }^{\circ} \mathrm{C}$ for $5 \mathrm{~min}$. followed by 30 cycles $\left(94^{\circ} \mathrm{C}\right.$ for 60 seconds, $58^{\circ} \mathrm{C}$ for 60 seconds and $72{ }^{\circ} \mathrm{C}$ for 60 seconds) and finishing with one cycle at $72{ }^{\circ} \mathrm{C}$ for $5 \mathrm{~min}$.

Statistical Analyses. Statistical analyses were conducted with the use of the Statistical Package for the Social Sciences program for Windows, version 20 (SPSS Inc., Chicago, IL, USA). Continuous clinical data were compared by unpaired Student's $t$-test, while the $\chi^{2}$ test was used to compare discrete variables. Data were expressed as mean $\pm \mathrm{SD}$ (standard deviation) (continuous variables) or as the number and percent of patients (categorical variables). All variables that showed significant differences by univariate analysis (with a $p$ values of $<0.05$ were considered significant) were analyzed together using a logistic regression method. A $p$ value of $<0.05$ was considered statistically significant. Deviation from Hardy-Weinberg equilibrium (HWE) was assessed by the exact test (http://ihg. gsf.de/).

\section{RESULTS}

The demographic and clinical data of the case and control groups are shown in Table 1 . There were no significant differences between the groups with respect to age, sex, duration of diabetes, diastolic blood pressure, 
body mass index (BMI), smoking status, duration of DR, serum hemoglobin $(\mathrm{Hb})$, estimated glomerular filtration rate (eGFR), TG and total HDL, LDL and cholesterol levels. However, statistically significant differences were observed in the duration of hypertension, systolic blood pressure, $\mathrm{Hb} \mathrm{A}_{1 \mathrm{c}}$, fasting-serum glucose, serum urea, serum creatinine, and urine albumin/creatinine ratio.

Differences in parameters reflecting renal function (serum creatinine, cystatin C, eGFR and urine albumin/ creatinine ratio) confirmed chronic kidney disease in the $\mathrm{DN}+$ group. Cystatin $\mathrm{C}$ was a better marker for the assessment of renal function than eGFR (MDRD equation
$\mathrm{mL} / \mathrm{min}$.). Cystatin $\mathrm{C}$ was significantly higher in the $\mathrm{DN}+$ group $(p<0.001)$ than in the control group. Univariate analysis demonstrated a statistically significant difference in genotype distribution in rs4340 genotypes (Table 2).

We used logistic regression analysis to evaluate whether this single nucleotide polymorphism (SNP) was independently associated with DN after adjusting for duration of hypertension, systolic blood pressure, cardiovascular disease, $\mathrm{DR}$, diabetic foot, $\mathrm{Hb} \mathrm{A}_{1 \mathrm{c}}$, serum fasting glucose, serum urea, serum creatinine, serum cystatin $\mathrm{C}$, urine albumin/creatinine ratio $(\mathrm{g} / \mathrm{mol})$, and found no statistically significant association of rs4340 with DN (Table 3).

Table 1. Clinical and laboratory characteristics of case and control groups

\begin{tabular}{|c|c|c|c|}
\hline Parameters & Cases (DN+) & Controls (DN-) & $p$ Value \\
\hline Number & 276 & 375 & \\
\hline Gender ( $\%$ males $)$ & 59.1 & 52.4 & 0.1 \\
\hline Age (years) & $64.75 \pm 9.15$ & $63.75 \pm 8.0$ & 0.13 \\
\hline Duration of T2DM (years) & $14.71 \pm 7.97$ & $14.60 \pm 6.73$ & 0.84 \\
\hline Duration of hypertension (years) & $12.23 \pm 9.88$ & $10.52 \pm 8.22$ & 0.02 \\
\hline Systolic blood pressure $(\mathrm{mmHg})$ & $155.27 \pm 18.92$ & $149.84 \pm 19.63$ & $<0.001$ \\
\hline Diastolic blood pressure (mmHg) & $84.87 \pm 11.63$ & $84.06 \pm 11.42$ & 0.36 \\
\hline Body mass index & $31.30 \pm 4.68$ & $30.77 \pm 5.00$ & 0.23 \\
\hline Active smokers $(\%)$ & 6.6 & 8.9 & 0.31 \\
\hline Serum $\mathrm{Hb} \mathrm{A}_{\mathrm{Ic}}(\%)^{\mathrm{a}}$ & $7.98 \pm 1.38$ & $7.65 \pm 1.14$ & 0.001 \\
\hline Serum-fasting glucose $(\mathrm{mmol} / \mathrm{L})$ & $9.03 \pm 2.76$ & $8.51 \pm 2.53$ & 0.01 \\
\hline $\mathrm{Hb}(\mathrm{g} / \mathrm{dL})$ & $13.94 \pm 1.49$ & $13.94 \pm 1.29$ & 0.99 \\
\hline Serum urea $(\mathrm{mmol} / \mathrm{L})$ & $7.35 \pm 3.73$ & $6.26 \pm 1.91$ & $<0.001$ \\
\hline $\begin{array}{l}\text { Serum creatinine }(\mu \mathrm{mol} / \mathrm{L}): \\
\text { Males }^{\mathrm{b}} \\
\text { Females }^{\mathrm{c}}\end{array}$ & $\begin{array}{r}93.13 \pm 58.21 \\
101.57 \pm 61.84^{\mathrm{b}} \\
79.70 \pm 49.21^{\mathrm{c}} \\
\end{array}$ & $\begin{array}{l}78.44 \pm 20.15 \\
84.28 \pm 19.93^{\mathrm{b}} \\
71.91 \pm 18.35^{\mathrm{c}} \\
\end{array}$ & $\begin{array}{l}<0.001 \\
<0.001^{\text {b }} \\
<0.001\end{array}$ \\
\hline $\begin{array}{l}\text { eGFR (MDRD equation; } \mathrm{mL} / \mathrm{min} .) \\
\text { Males }^{\mathrm{b}} \\
\text { Females }^{\mathrm{c}}\end{array}$ & $\begin{array}{c}72.60 \pm 19.74 \\
71.97 \pm 19.45^{\mathrm{b}} \\
74.31 \pm 20.72^{\mathrm{c}} \\
\end{array}$ & $\begin{array}{r}75.22 \pm 15.16 \\
77.66 \pm 14.33^{\mathrm{b}} \\
72.45 \pm 15.69^{\mathrm{c}} \\
\end{array}$ & $\begin{array}{c}0.22 \\
\mathbf{0 . 0 0 2}^{\mathrm{b}} \\
0.13^{\mathrm{c}} \\
\end{array}$ \\
\hline Serum cystatin C (mg/L) & $0.95 \pm 0.48$ & $0.78 \pm 0.21$ & $<0.001$ \\
\hline Serum total cholesterol $(\mathrm{mmol} / \mathrm{L})$ & $4.62 \pm 1.17$ & $4.55 \pm 0.99$ & 0.42 \\
\hline Serum HDL cholesterol (mmol/L) & $1.23 \pm 0.35$ & $1.26 \pm 0.36$ & 0.29 \\
\hline Serum LDL cholesterol $(\mathrm{mmol} / \mathrm{L})$ & $2.59 \pm 0.95$ & $2.57 \pm 0.80$ & 0.73 \\
\hline Serum TG cholesterol $(\mathrm{mmol} / \mathrm{L})$ & $2.08 \pm 1.60$ & $1.83 \pm 1.24$ & 0.04 \\
\hline Urine albumin/creatinine ratio ( $\mathrm{g} / \mathrm{mol})$; sample \#1 & $27.49 \pm 55.46$ & $1.57 \pm 3.05$ & $<0.001$ \\
\hline Urine albumin/creatinine ratio $(\mathrm{g} / \mathrm{mol})$; sample \#2 & $23.13 \pm 39.34$ & $1.60 \pm 3.67$ & $<0.001$ \\
\hline Urine albumin/creatinine ratio $(\mathrm{g} / \mathrm{mol})$; sample $\# 3$ & $23.36 \pm 42.49$ & $1.62 \pm 2.49$ & $<0.001$ \\
\hline
\end{tabular}

DN+: cases; DN-: controls; T2DM: type 2 diabetes mellitus; Hb: hemoglobin; eGFR: estimated glomerular filtration rate; MDRD: modification diet in renal disease; HDL: high-density lipoproteins; LDL: low-density lipoproteins; TG: triglycerides. The values represent mean \pm SD (standard deviation); statistically significant results are bold.

a The average value for $\mathrm{Hb} \mathrm{A}$

${ }^{\mathrm{b}}$ Comparison of men who are $\mathrm{DN}+v s$. men who are $\mathrm{DN}-$.

${ }^{c}$ Comparison women who are $\mathrm{DN}+v s$. women who are $\mathrm{DN}-$. 
Table 2. Distribution of the rs 4340 genotypes and alleles in $\mathrm{DN}+$ patients (cases) and in DN-controls.

\begin{tabular}{|l|c|c|c|}
\hline Parameters & Cases $(\boldsymbol{n}=\mathbf{2 7 6})$ & Controls $(\boldsymbol{n}=\mathbf{3 7 5})$ & $\boldsymbol{p}$ Value \\
\hline rs4340 & & & $115(30.7)$ \\
\hline DD genotype (\%) & $90(32.8)$ & $169(45.0)$ & 0.02 \\
\hline ID genotype (\%) & $143(51.7)$ & $91(24.3)$ & 0.06 \\
\hline II genotype (\%) & $43(25.5)$ & $399(53.2)$ & \\
\hline D allele (\%) & $323(58.5)$ & $351(46.8)$ & \\
\hline I allele (\%) & $229(41.5)$ & 0.07 & \\
\hline PHWE & 0.3 & & \\
\hline
\end{tabular}

a PHWE: values were computed using Pearson's goodness-of-fit $\chi^{2}(1 \mathrm{df})$ test.

Table 3. Association of rs4340 polymorphisms with DN in Caucasians with logistic regression.

\begin{tabular}{|l|c|c|c|c|c|}
\hline $\begin{array}{l}\text { Inheritance } \\
\text { Model }\end{array}$ & Genotype & Cases $(\boldsymbol{n}=\mathbf{2 7 6})$ & Controls $(\boldsymbol{n}=\mathbf{3 7 5})$ & $\begin{array}{c}\text { Unadjusted OR } \\
\mathbf{( 9 5 \%} \mathbf{C I}) / \boldsymbol{p} \text { Value }\end{array}$ & $\begin{array}{c}\text { Adjusted OR } \\
\mathbf{( 9 5 \%} \text { CI) } \boldsymbol{p} \text { Value }\end{array}$ \\
\hline rs4340 & & & & & \\
\hline Codominant & DD & $90(32.8 \%)$ & $115(30.7 \%)$ & $1.03(0.39-2.72) / 0.9$ & $0.80(0.29-2.25) / 0.7$ \\
\hline & ID & $143(51.7 \%)$ & $169(45.0 \%)$ & $1.54(0.61-3.90) / 0.4$ & $1.32(0.49-3.53) / 0.6$ \\
\hline & II & $43(15.5 \%)$ & $91(24.3)$ & Reference & Reference \\
\hline
\end{tabular}

OR: odds ratio; $95 \%$ CI: 95\% confidence interval.

${ }^{a} p$ Values were adjusted for duration of hypertension, systolic blood pressure, cardiovascular disease, DR, diabetic foot, Hb A $\mathrm{A}_{1 \mathrm{c}}$, serum-fasting glucose, serum urea, serum creatinine, serum cystatin $\mathrm{C}$, urine albumin/creatinine ratio (g/mol): samples \#1/\#3.

\section{DISCUSSION}

In our cross-sectional study we found no association between rs4340 of the $A C E$ gene and DN in Caucasians with T2DM. Conflicting reports have been made in different populations on the association between the I/D polymorphism in the $A C E$ gene (rs4340) and DN. Our findings are in accordance with the study in French subjects with T2DM, but they differ from most studies performed in Chinese, Japanese and Indian populations, as well as in two meta-analyses in Asian and Arab patients with T2DM [13,19,20,23,25-29].

Wide inter-ethnic differences have been reported for allele/genotype frequencies of the I/D polymorphism of the $A C E$ gene (rs4340), and these differences have been assumed to be responsible for the contradictory results among association studies in subjects with DN [13,19, 20,23-26]. An association between rs4340 and DN was demonstrated in Asian populations (Japan, South India) [20,23] but not in Iran [31] and Malaysia [32]. A metaanalysis has demonstrated that the $A C E$ I/D gene polymorphism affected the development of DN, i.e., that the $\mathrm{D}$ allele was a risk factor for $\mathrm{DN}$, and I allele was a protective factor against DN in T2DM in an Asian population [26,33]. Another meta-analysis [27] reported that $A C E$ I/D gene polymorphism (rs4340) was associated with T2DM in an
Arab population. Moreover, the D/D genotype (rs4340) was reported to be an independent risk factor for renal end points in Chinese patients with T2DM [24]. Wang et al. [34] have recently demonstrated an association between the D allele (rs4340) and glomerular filtration impairment in Chinese patients with T2DM.

There were only a few reports in Caucasians [25,28, 29]. In a large case-control study, which enrolled patients in France, Finland and Denmark, it was shown that the rs4340 was associated with DN in subjects with type 1 diabetes mellitus (T1DM) [29]. Additionally, the D allele (rs4340) was reported to be an independent risk factor for both the onset and the progression of DN in T1DM patients [30]. Moreover, Yu et al. [25] reported that the DD genotype (rs4340) was associated with the end-stage renal disease in DN patients with T2DM. Contrary to the association between rs4340 and DN in T1DM, Hadjadj et al. [28] were not able to demonstrate an association between the rs4340 and DN in French subjects with T2DM, whereas so far, there have been no reports of rs4341 and $\mathrm{DN}$ in Caucasians.

A limitation of our study was the use of cross-sectional data in the analyses, restricting the possibility of causal inferences from our data. Another limitation of the study was the sample size. The strength of our crosssectional study was a rather large community-based sample 
of Caucasians with T2DM, and the detailed phenotypic characterization of the subjects with DN. In conclusion, rs4340 of the $A C E$ gene was not demonstrated to be a potential genetic marker for DN in Caucasians with T2DM.

Declaration of Interest. The authors report no conflicts of interest. The authors alone are responsible for the content and writing of this article.

\section{REFERENCES}

1. Ritz E, Orth SR. Nephropathy in patients with type 2 diabetes mellitus. N Engl J Med. 1999; 341(15): 1127-1133.

2. Conway BR, Maxwell AP. Genetics of diabetic nephropathy: Are there clues to the understanding of common kidney diseases? Nephron Clin Pract 2009; 112(4): 213-221.

3. Gross JL, de Azevedo MJ, Silveiro SP, Canani LH, Caramori ML, Zelmanovitz T. Diabetic nephropathy: Diagnosis, prevention, and treatment. Diabetes Care. 2005; 28(1): 164-176.

4. Carpena MP, Rados DV, Sortica DA, deSouza BM, Reis AF, Canani LH, et al. Genetics of diabetic nephropathy. Arq Bras Endocrinol Metab. 2010; 54(3): 254-261.

5. Kato M, Natarajan R. Diabetic nephropathy-emerging epigenetic mechanisms. Nat Rev Nephrol. 2014; 10(9): 517-530.

6. Bouchard J, Macedo E, Soroko S, Chertow GM, Himmelfarb J, Ikizler TA, et al. Comparison of methods for estimating glomerular filtration rate in critically ill patients with acute kidney injury. Nephrol Dial Transplant. 2010; 25(1): 102-107.

7. Evans TC, Capell P. Diabetic nephropathy. Clin Diabetes. 2000; 18(1). (http://journal.diabetes.org/clinical diabetes/v18n12000/Pg7.htm.7)

8. Appel GB, Radhakrishnan J, Avram MM, DeFronzo RA, Escobar-Jimenez F, Campos MM, et al.; RENAL Study. Analysis of metabolic parameters as predictors of risk in the renal study. Diabetes Care. 2003; 26(5): 1402-1407.

9. Yacoub R, Campbell KN. Inhibition of RAS in diabetic nephropathy. Int J Nephrol Renovasc Dis. 2015; 8(1): 29-40.

10. Gnudi L, Goldsmith D. Renin angiotensin aldosterone system (RAAS) inhibitors in the prevention of early renal disease in diabetes. F1000 Med Rep. 2010; 2. pii: 18. doi: 10.3410/M2-18.
11. Movva S, Alluri RV, Komandur S, Vattam K, Eppa $\mathrm{K}$, Mukkavali KK, et al. Relationship of angiotensin-converting enzyme gene plymorphism with nephropathy associated with type 2 diabetes mellitus in Asian Indians. J Diabetes Complications. 2007; 21(4): 237-241.

12. Moon JY. Recent update of renin-angiotensin-aldosterone system in the pathogenesis of hypertension. Electrolyte Blood Press. 2013; 11(2): 41-45.

13. Zhou TB, Qin YH, Su LN, Lei FY, Huang WF, Zhao $\mathrm{YJ}$, et al. The association between angiotensin-converting enzyme insertion/deletion gene variant and risk of focal segmental glomerulosclerosis: A systematic review and meta-analysis. J Renin Angiotensin Aldosterone Syst. 2011; 12(4): 624-633.

14. Glenn KL, Du ZQ, Eisenmann JC, Rothschild MF. An alternative method for genotyping of the ACE I/D polymorphism. Mol Biol Rep. 2009; 36(6): 1305-1310.

15. Zhou TB, Yin SS, Qin YH. Association between angiotensin-converting enzyme insertion/deletion gene polymorphism and end-stage renal disease susceptibility. J Renin Angiotensin Aldosterone Syst. 2014; 15(1): 22-31.

16. World Health Organisation, Part 1: Diagnosis and Clasification of Diabetes Mellitus: Report of a WHO consultation, In: Alwan A, King H. Definition, diagnosis and classification of diabetes mellitus and its complications. World Health Department of Noncommunicable Disease Surveillance, Geneva, Switzerland, 1999.

17. Rigat B, Hubert C, Corvol P, Soubrier F. PCR detection of the insertion/deletion polymorphism of the human angiotensin converting enzyme gene. Nucleic Acids Res. 1992; 20(6): 1433.

18. Shlipak M. Diabetic nephropathy. Clinical Evidence (Online), 2009,0606. Pii: 0606. Review. PubMed PMID: 19445773. PubMed Central PMCID: PMC290779.

19. Kumar R, Sharma RK, Agarwal S. Genetic predisposition for development of nephropathy in type 2 diabetes mellitus. Biochem Genet. 2013; 51(11-12): 865-875.

20. Gohda T, Makita Y, Shike T, Kobayashi M, Funabiki $\mathrm{K}$, Haneda M, et al. Association of the DD genotype and development of Japanese type 2 diabetic nephropathy. Clin Nephrol. 2001; 56(6): 475-480. 
21. Hojs R, Bevc S, Ekart R, Gorenjak M, Puklavec L. Serum cystatin C-based formulas for prediction of glomerular filtration rate in patients with chronic kidney disese. Nephron Clin Pract. 2010; 114(2): c118-c126.

22. Bevc S, Hojs R, Ekart R, Gorenjak M, Puklvec L. Simple cystatin C formula compared to sophisticated CKD-EPI formulas for estimation of glomerular filtration rate in the elderly. Ther Apher Dial. 2011; 15(3): 261-268.

23. Viswanathan V, Zhu Y, Bala K, Dunn S, Snehalatha C, Ramachandran A, et al. Association between ACE gene polymorphism and diabetic nephropathy in South Indian patients. JOP. 2001; 2(2): 83-87.

24. Wang Y, Ng MC, So WY, Tong PC, Ma RC, Chow $\mathrm{CC}$, et al. Prognostic effect of insertion/deletion polymorphism of the ace gene on renal and cardiovascular clinical outcomes in Chinese patients with type 2 diabetes. Diabetes Care. 2005; 28(2): 348-354.

25. Yu ZY, Chen LS, Zhang LC, Zhou TB. Meta-analysis of the relationship between ACE I/D gene polymorphism and end-stage renal disease in patients with diabetic nephropathy. Nephrology (Carlton). 2012; 17(5): 480-487.

26. Zhong W, Jiang Z, Zhou TB. Association between the ACE I/D gene polymorphism and T2DN susceptibility: The risk of T2DM developing into T2DN in the Asian population. J Renin Angiotensin Aldosterone Syst. 2015; 12(1): 1-9.

27. Al-Rubeaan K, Siddiqui K, Saeb AT, Nazir N, AlNaqeb D, Al-Qasim S. ACE I/D and MTHFR C677T poly-morphisms are significantly associated with type 2 diabetes in Arab ethnicity: A meta-analysis. Gene. 2013; 520(2): 166-177.

28. Hadjadj S, Fumeron F, Roussel R, Saulnier PJ, Gallois Y, Ankotche A, et al.; DIABHYCAR Study Group; DIAB2NEPHROGENE Study Group; SURDIAGENE Study Group. Prognostic value of the insertion/deletion polymorphism of the ACE gene in type 2 diabetic subjects: Results from the mon-insulin- dependent diabetes, hypertension, microalbuminuria or proteinuria, cardiovascular events, and ramipril (DIABHYCAR), diabete de type 2, nephropathie et genetique (DIAB2NEPHROGENE), and survie, diabete de type 2 et genetique (SURDIAGENE) studies. Diabetes Care. 2008; 31(9): 1847-1852.

29. Hadjadj S, Tarnow L, Forsblom C, Kazeem G, Marre M, Groop PH, et al.; EURAGEDIC (European Rational Approach for Genetics of Diabetic Complications) Study Group. Association between angiotensinconverting enzyme gene polymorphisms and diabetic nephropathy: Case-control, haplotype, and familybased study in three European populations. J Am Soc Nephrol. 2007; 18(4): 1284-1291.

30. Hadjadj S, Belloum R, Bouhanick B, Gallois Y, Guilloteau G, Chatellier G, et al. Prognostic value of angiotensin-I converting enzyme I/D polymorphism for nephropathy in type 1 diabetes mellitus: A prospective study. J Am Soc Nephrol. 2001; 12(3): 541-549.

31. Nikzamir A, Rashidi A, Esteghamati A, Nakh-javani M, Golmohammadi T, Khalilzadeh $\mathrm{O}$. The relationship between ACE gene insertion/deletion polymorphism and diabetic retinopathy in Iranian patients with type 2 diabetes. Ophthalmic Genet. 2010; 31(3): 108-113.

32. Jayapalan JJ, Muniandy S, Chan SP. Null association between ACE gene I/D polymorphism and diabetic nephropathy among multiethnic Malaysian subjects. Indian J Hum Genet. 2010; 16(2): 78-86.

33. Wang F, Fang Q, Yu N, Zhao D, Zhang Y, Wang J, et al. Association between genetic polymorphism of the angiotensin-converting enzyme and diabetic nephropathy: A meta-analysis comprising 26,580 subjects. J Renin Angiotensin Aldosterone Syst. 2012; 13(1): 161-174.

34. Wang M, Zhang X, Song X, Zou X, Wu W, Wang Y, et $a l$. Nodular glomerulosclerosis and renin angiotensin system in Chinese patients with type 2 diabetes. Mol Cell Endocrinol. 2016; 427(3):92-100. 